\title{
Design of Foundation of Steel Structure for Fractionation Plant
}

\author{
Saurabh Dewarde ${ }^{1}$, Shubham Kanade ${ }^{2}$, Ankit Karde ${ }^{3}$, Rohan Mane ${ }^{4}$, Mr. Manjunath M $^{5}$ \\ 1,2,3,4 (UG Students), 5 Assistant Professor, \\ Department of Civil Engineering, St John College of Engineering \& Management, Palghar. Maharashtra 401404
}

DOI: 10.46335/IJIES.2020.5.7.1

\begin{abstract}
In Oil \& Gas, Refinery \& Power Plants different types of Equipment's plays a major role for process requirements. Majority of equipment are categorized into Horizontal Vessels, Vertical vessels, Exchangers, Storage tanks. These are further divided into Static equipment and Dynamic equipment based on rotations and vibration. Equipment Foundations design is major challenge for Structural Engineers to withstand process loads and Environmental loads for different load combination in terms of safety and economy. Most of the Vertical equipment Foundation are Octagonal in shape for Constructability point of view and economy point of view. In the present project Equipment Foundation has been analyzed by using Staad Software and designed by using International codes as per American code of institute.
\end{abstract}

Keywords - Horizontal Vessels, Vertical vessels, Foundation.

\section{1- INTRODUCTION}

1.1 General: Foundations are substructures that are constructed below the ground level which support the superstructures above the ground level. The main function of the footing or foundation is to

- $\quad$ Transmit the load safely and effectively coming on to it to the underlying soil without exceeding the "Safe bearing capacity of the soil".

- Ensuring that the settlements of the structure are within the permissible limits.
- In addition to that, the foundation should provide adequate safety against possible instability due to overturning, sliding and uplift.

- The design is carefully done so that foundation has to provide adequate steel to resist tensile forces and at the same time it should be verified that more steel than required should not be placed as it gives brittle failure.

\subsection{Types Of Equipment Foundations:}

- Vertical Vessel Foundation

- Horizontal Vessel Foundation

\subsubsection{Vertical Vessel Foundation:}

Vertical vessels are process equipment placed vertically on either foundation at grade either in a concrete or steel structure. Vertical vessels are cylindrical in shape with each end capped by a domed cover called a head. The length to diameter ratio of a vertical vessel is typically $3: 1$. Vertical vessels are usually supported by legs, lugs and skirts. They can be Short and stubby or tall and slim.

\subsubsection{Horizontal Vessel Foundation:}

Horizontal vessels are relatively large diameter cylindrical pressure vessel used for variety of pressure functions. The height above grade is usually determined by NPSH requirements of pumps in the liquid outlet line or gravity flow requirement to other equipment. Foudation type is similar to both of them. Horizontal vessels are usually supported on fixed end saddle and sliding end saddle. 


\section{II- METHOLOGY}

2.1 Vertical Vessel:

\subsubsection{Vessel 1:}

\begin{tabular}{|l|l|l|}
\hline Table 1 & Operating & Empty \\
\hline Live load & $1 \mathrm{kN} / \mathrm{m}^{2}$ & $1 \mathrm{kN} / \mathrm{m}^{2}$ \\
\hline Dead load & $10488.834 \mathrm{kN}$ & $6307.464 \mathrm{kN}$ \\
\hline Shear & $324.739 \mathrm{kN}$ & $119.884 \mathrm{kN}$ \\
\hline Moment & $10827.890 \mathrm{kNm}$ & $6511.38 \mathrm{kNm}$ \\
\hline
\end{tabular}
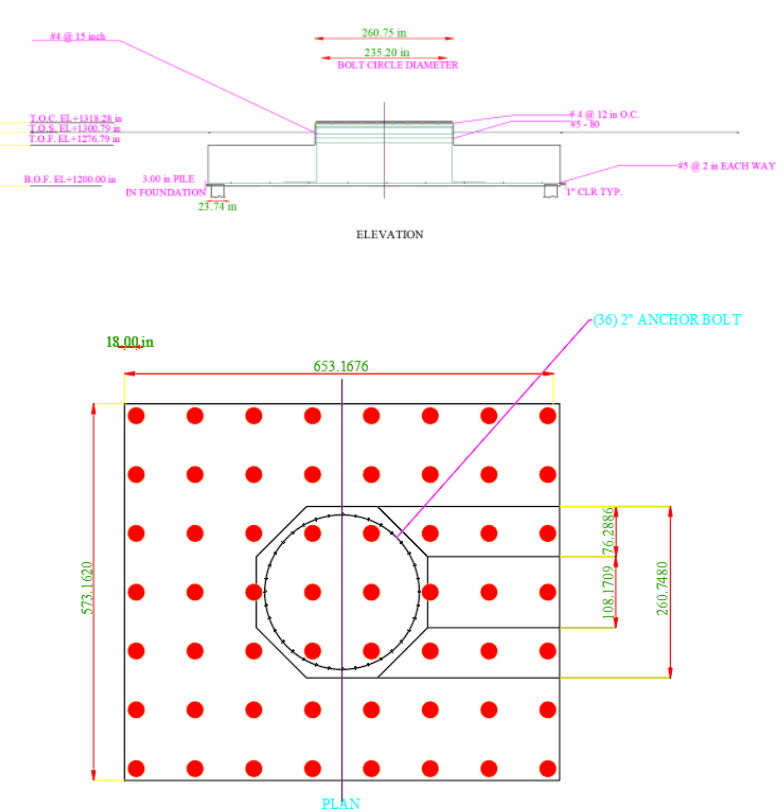

Fig. 1, 2 - fig shows the STAAD Foundation output

\begin{tabular}{|c|c|c|c|}
\hline \multicolumn{2}{|c|}{ Table 2: Anchor Bolt } & \multicolumn{2}{|c|}{ Table 3: Pedestal: } \\
\hline \multirow[t]{2}{*}{ Grade } & \multirow{2}{*}{$\begin{array}{l}\text { F1554 } \\
\text { Grade } 36\end{array}$} & Geometry & Octagonal \\
\hline & & Length of & $2.747 \mathrm{~m}$ \\
\hline \multirow{2}{*}{$\begin{array}{l}\text { Tensile } \\
\text { strength }\end{array}$} & \multirow{2}{*}{$\begin{array}{l}399895.5 \\
\mathrm{kN} / \mathrm{m}^{2}\end{array}$} & eacin side & \\
\hline & & Height of & $1.053 \mathrm{~m}$ \\
\hline \multirow{2}{*}{$\begin{array}{l}\text { Yield } \\
\text { strength }\end{array}$} & \multirow{2}{*}{$\begin{array}{l}248211 \\
\mathrm{kN} / \mathrm{m}^{2}\end{array}$} & pede & \\
\hline & & Area & $36.188 \mathrm{~m}^{2}$ \\
\hline Diameter & $0.069 \mathrm{~m}$ & & \\
\hline
\end{tabular}

\subsubsection{Vessel 2:}

\begin{tabular}{|l|l|l|}
\hline Table 4 & Operating & Empty \\
\hline Live load & $1 \mathrm{kN} / \mathrm{m}^{2}$ & $1 \mathrm{kN} / \mathrm{m}^{2}$ \\
\hline Dead load & $10562.98 \mathrm{kN}$ & $\begin{array}{l}5744.472 \\
\mathrm{kN}\end{array}$ \\
\hline Shear & $328.129 \mathrm{kN}$ & $40.085 \mathrm{kN}$ \\
\hline Moment & 15612.58 & $\begin{array}{l}8483.188 \\
\mathrm{kNm}\end{array}$ \\
& $\mathrm{kNm}$ & \\
\hline
\end{tabular}
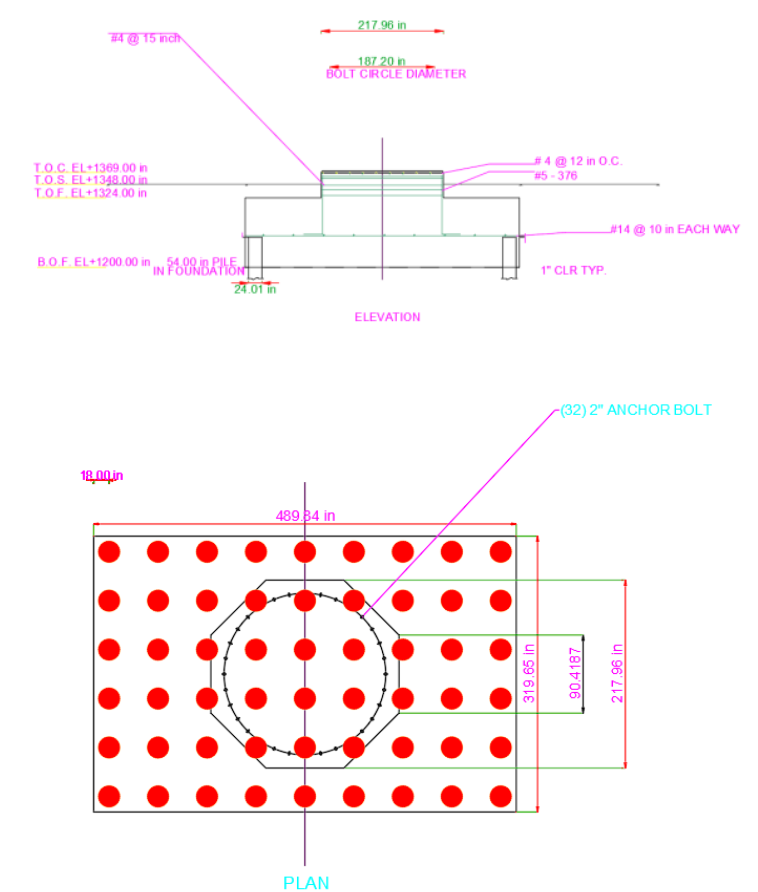

Fig. 3, 4: fig shows the STAAD Foundation output

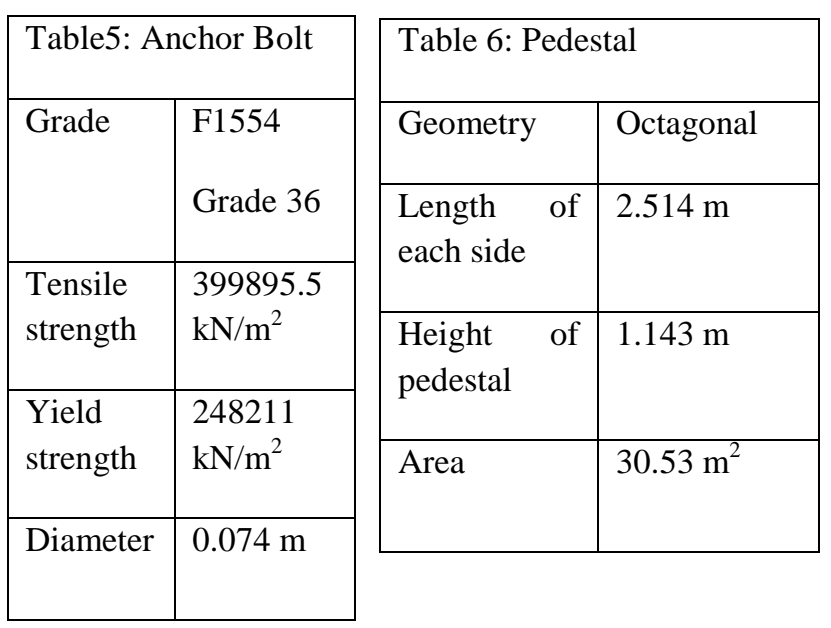


International Journal of Innovations in Engineering and Science, Vol 5, No.7, 2020

$w w w . i j i e s . n e t$

2.1.3 Vessel 3:

\begin{tabular}{|l|l|l|}
\hline Table 7 & Operating & Empty \\
\hline Live load & $1 \mathrm{kN} / \mathrm{m}^{2}$ & $1 \mathrm{kN} / \mathrm{m}^{2}$ \\
\hline Dead load & $6848.7 \mathrm{kN}$ & $2759.016 \mathrm{kN}$ \\
\hline Shear & $212.694 \mathrm{kN}$ & $85.681 \mathrm{kN}$ \\
\hline Moment & $11787.795 \mathrm{kNm}$ & $4748.594 \mathrm{kNm}$ \\
\hline
\end{tabular}

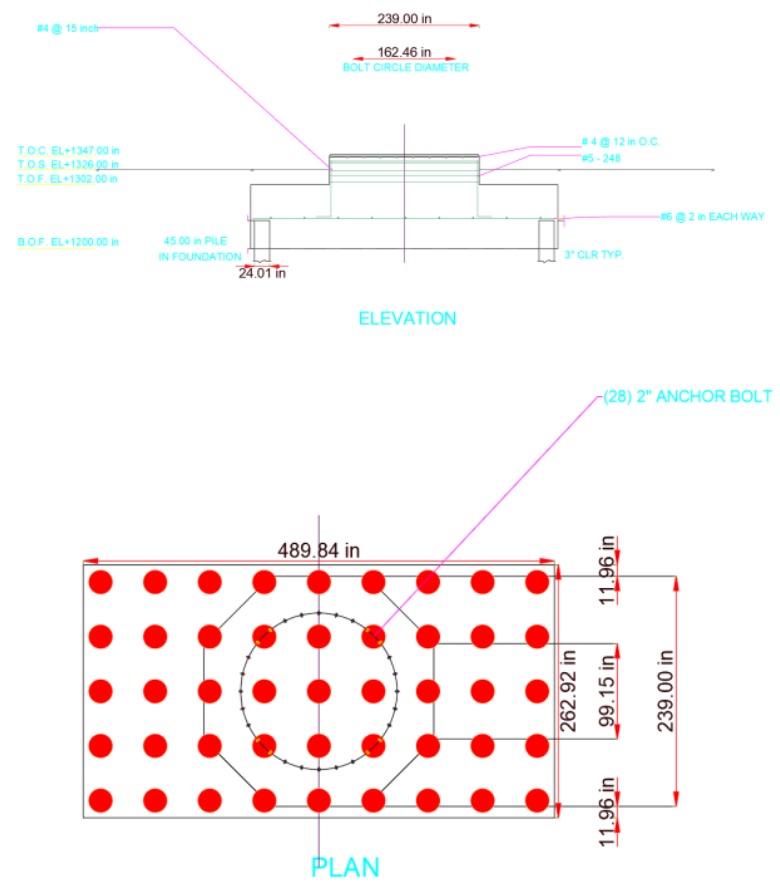

Fig. 5, 6: fig shows the STAAD Foundation output

\begin{tabular}{|l|l|}
\hline \multicolumn{2}{|l|}{ Table 8: Anchor Bolt } \\
\hline Grade & $\begin{array}{l}\text { F1554 } \\
\text { Grade 36 }\end{array}$ \\
\hline $\begin{array}{l}\text { Tensile } \\
\text { strength }\end{array}$ & $\begin{array}{l}399895.5 \\
\mathrm{kN} / \mathrm{m}^{2}\end{array}$ \\
\hline $\begin{array}{l}\text { Yield } \\
\text { strength }\end{array}$ & $\begin{array}{l}248211 \\
\mathrm{kN} / \mathrm{m}^{2}\end{array}$ \\
\hline Diameter & $0.069 \mathrm{~m}$ \\
\hline
\end{tabular}

2.2 Horizontal Vessel:

\subsubsection{Vessel 1:}

Seismic in transverse direction (for sliding):

\begin{tabular}{|l|l|l|}
\hline Table 10 & Operating & Empty \\
\hline Shear & $32.6 \mathrm{kN}$ & $20.514 \mathrm{kN}$ \\
\hline Moment & $146.453 \mathrm{kN} . \mathrm{m}$ & $90.201 \mathrm{kN} . \mathrm{m}$ \\
\hline
\end{tabular}

Seismic in longitudinal direction (for sliding):

\begin{tabular}{|l|l|l|}
\hline Table 11 & Operating & Empty \\
\hline Shear & $24.241 \mathrm{kN}$ & $15.247 \mathrm{kN}$ \\
\hline $\begin{array}{l}\text { Vertical } \\
\text { load }\end{array}$ & $9.924 \mathrm{kN} . \mathrm{m}$ & $6.242 \mathrm{kN} . \mathrm{m}$ \\
\hline
\end{tabular}

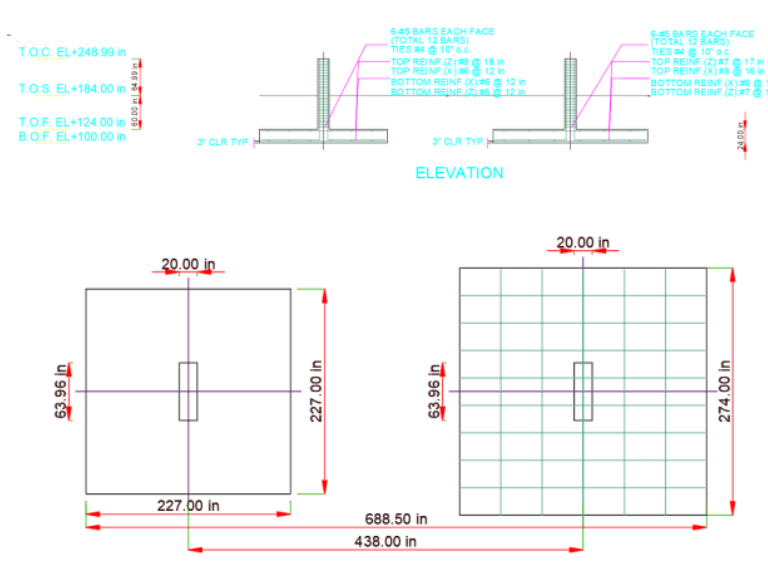

Fig 7,8- shows the STAAD Foundation output

Seismic in transverse direction (for fixed):

\begin{tabular}{|l|l|l|}
\hline Table 12 & Operating & Empty \\
\hline Shear & $48.127 \mathrm{kN}$ & $30.304 \mathrm{kN}$ \\
\hline Moment & $216.399 \mathrm{kN} . \mathrm{m}$ & $\begin{array}{l}136.141 \\
\text { kN.m }\end{array}$ \\
\hline
\end{tabular}

Seismic in longitudinal direction (for fixed): 


\begin{tabular}{|l|l|l|}
\hline Table 13 & Operating & Empty \\
\hline Shear & $56.574 \mathrm{kN}$ & $35.539 \mathrm{kN}$ \\
\hline $\begin{array}{l}\text { Vertical } \\
\text { load }\end{array}$ & $9.924 \mathrm{kN.m}$ & $6.242 \mathrm{kN}$. \\
\hline
\end{tabular}

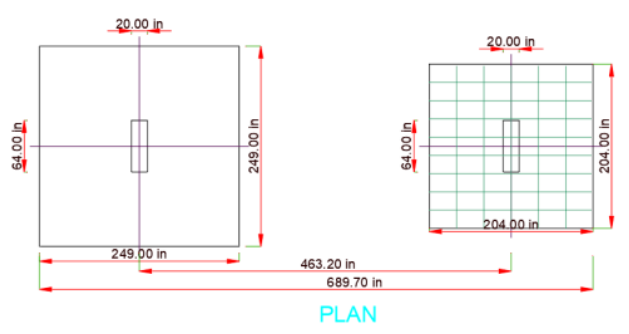

\subsubsection{Vessel 2:}

Seismic in transverse direction (for sliding):

\begin{tabular}{|l|l|l|}
\hline Table 14: & Operating & Empty \\
\hline Shear & $27.755 \mathrm{kN}$ & $13.415 \mathrm{kN}$ \\
\hline Moment & $136.352 \mathrm{kN} . \mathrm{m}$ & $65.891 \mathrm{kN} . \mathrm{m}$ \\
& & \\
\hline
\end{tabular}

Seismic in transverse direction (for fixed):

\begin{tabular}{|l|l|l|}
\hline Table 15 & Operating & Empty \\
\hline Shear & $38.564 \mathrm{kN}$ & $18.628 \mathrm{kN}$ \\
\hline Moment & $189.635 \mathrm{kN} . \mathrm{m}$ & $91.504 \mathrm{kN} . \mathrm{m}$ \\
& & \\
\hline
\end{tabular}

Seismic in longitudinal direction (for sliding):

\begin{tabular}{|l|l|l|}
\hline Table 16 & Operating & Empty \\
\hline Shear & $19.922 \mathrm{kN}$ & $9.612 \mathrm{kN}$ \\
\hline Vertical load & $8.46 \mathrm{kN} . \mathrm{m}$ & $4.083 \mathrm{kN} . \mathrm{m}$ \\
& & \\
\hline
\end{tabular}

Seismic in longitudinal direction (for fixed):

\begin{tabular}{|l|l|l|}
\hline Table 17 & Operating & Empty \\
\hline Shear & $46.486 \mathrm{kN}$ & $22.435 \mathrm{kN}$ \\
\hline Vertical load & $8.46 \mathrm{kN} . \mathrm{m}$ & $4.083 \mathrm{kN} . \mathrm{m}$ \\
& & \\
\hline
\end{tabular}

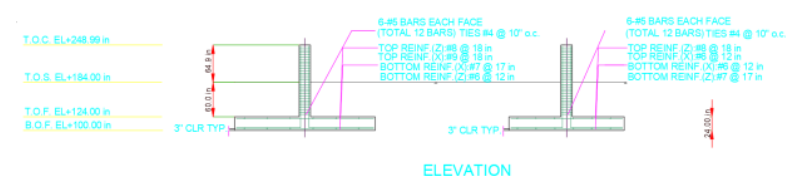

Fig. 9: fig shows the STAAD Foundation output
Fig. 10: fig shows the STAAD Foundation output

\section{III- CONCLUSIONS:}

The conclusions as per the result obtain from the STAAD foundation:

We came into conclusion that:

1. For vertical vessel 1: the value calculated for the overturning moment is slightly increased. The manually calculated value was $\mathbf{1 8 6 1 2 . 9 5 6}$ kip-ft while STAAD calculated the value was 164002.586 kip-ft. due to which there is change in no. of dowels. Through manual calculation it was 50 Nos. and the STAAD result was 80 Nos. also STAAD foundation has calculated checks for one way shear which found out to be safe.

2. For vertical vessel 2: the value calculated for the overturning moment is slightly increased. The manually calculated value was $\mathbf{3 2 0 4 0 . 9 7 1}$ kip-ft while STAAD calculated the value was 442375.553 kip-ft. due to which there is change in no. of dowels. Through manual calculation it was 50 Nos. and the STAAD result was $\mathbf{3 7 6}$ Nos. also STAAD foundation has calculated checks for one way shear which found out to be safe.

3. For vertical vessel 3 : the value calculated for the overturning moment is slightly increased. The manually calculated value was 18353.735kip-ft while STAAD calculated the value was 290123.983 kip-ft. due to which there is change in no. of dowels. Through manual calculation it was $\mathbf{5 0}$ Nos. and the STAAD result was 248 Nos. The tensile force also changes. while STAAD value was $\mathbf{1 6 . 7 0 6}$ kip-ft. also STAAD foundation has calculated checks for one way shear which found out to be safe.

4. For horizontal vessel 1: the footing geometry provided for fixed and sliding saddle was identical. The minimum length provided was $\mathbf{1 5}$ ft and maximum was $\mathbf{2 5} \mathbf{f t}$. but the final length 
and width of vessel adopted was $\mathbf{1 8 . 9 1} \mathbf{f t}$. with

\section{www. ijies.net}

depth same as provided $\mathbf{2 f t}$.if we provide load combination in STAAD Foundation as per PIP we can see that the Foundation is failing in bearing check as well as the footing size is inadequate so to avoid such errors we will provide the load combination as per ASCE 705 .

5. For horizontal vessel 2: the footing geometry provided for fixed and sliding saddle was identical. The minimum length provided was $\mathbf{1 5}$ ft and maximum was $25 \mathrm{ft}$. but the final length and width of vessel adopted was $\mathbf{2 0 . 7 5} \mathbf{f t}$. with depth same as provided $\mathbf{2 f t}$.if we provide load combination in STAAD Foundation as per PIP we can see that the Foundation is failing in bearing check as well as the footing size is inadequate so to avoid such errors we will provide the load combination as per ASCE 705.

\section{REFERENCES}

[1] Finite Element Analysis Software - STAAD Foundation, STAAD Pro, AutoCAD Naviswork.

[2] ACI (American concrete institute)-Concrete code ACI - 318-11

[3] ASCE (American society of civil engineer )-Loading code-ASCE-SEI-7-10

[4] PIP (Process industry practices)-Structural codeSTE05121-STE03360

[5] Structural magazine - Burns \& McDonnell performed an Engineer, Procure, Construct contract for a new NGL Fractionation Plant for ONEOK Hydrocarbon, L.P. located in Mont Belvieu, TX.

[6] Tutorial links

a. https://www.youtube.com./watch? $v=$ G2elijkignZ $8 \& t=226 s-$ Horizontal Vessel Foundation Isolated design

b. https://www.youtube.com./watch?v=hZ_5G6qdz $M U \& t=1550 s-$ For loading criteria 